\title{
Application of Organic Fertilizer Tithonia Plus to Control Iron Toxicity and Reduce Commercial Fertilizer Application on New Paddy Field
}

\author{
Nurhajati Hakim ${ }^{1}$, Agustian $^{1}$ and Yanti Mala ${ }^{2}$ \\ ${ }^{1}$ Soil Science Department, Faculty of Agriculture Andalas University, \\ Campuss Limau Manis, Padang 25163, Indonesia. Phone/Fax: 0751-72773/72702, \\ e-mail: nhakimsa@yahoo.co.id \\ ${ }^{2}$ Centre for Assessment Agricultural Technology (BPTP) West Sumatra \\ Received 30 June 2011 / accepted 16 May 2012
}

\begin{abstract}
Ferrous toxicity is a one of the problems most often found in lowland rice systems in tropical and sub-tropical region especially in new paddy field (NPF) on Ultisols and Oxisols. Flooding during rice growth creates a chemically reduced state in soils causing reduction of insoluble $\left(\mathrm{Fe}^{3+}\right)$ to soluble $\left(\mathrm{Fe}^{2+}\right)$ form even at excessive level. Excessive $\mathrm{Fe}^{2+}$ uptake is eventually the main cause of iron toxicity. The purpose of this study was to find an appropriate formulation of organic fertilizer Tithonia plus (OFTP) to control the iron toxicity, reduce the application of commercial fertilizers $(\mathrm{CF})$ and increase rice production at various ages of NPF. The field experiment was conducted in farmer fields in Sitiung, Koto Baru sub-district, Dharmasraya district of West Sumatra province. Experimental design used was a factorial 2 x 6 in a split plot design. The main plot (A), the age of the opening of NPF were: 0 year; and 2 years;

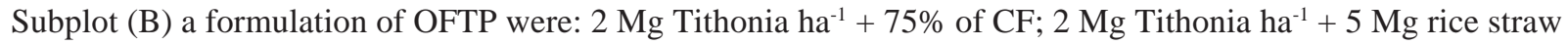

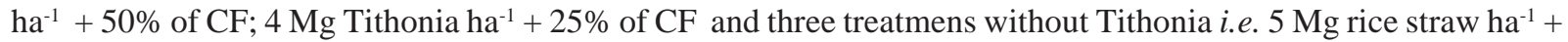
$75 \%$ of CF; $2 \mathrm{Mg}$ animal cow manure ha ${ }^{-1}+75 \%$ of CF, and $100 \%$ of CF. Liming with $500 \mathrm{~kg} \mathrm{CaCO}_{3} \mathrm{ha}^{-1}$ were applied for all treatments. The results showed the use of OFTP increased the nutrients availability such as N, P, and K on NPF and control the iron toxicity. The appropriate formulation of OFTP to control the iron toxicity and reduced the

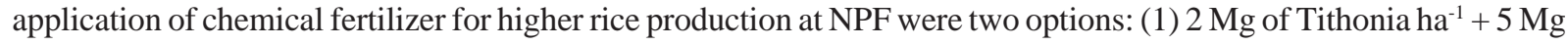
of rice straw ha ${ }^{-1}+50 \%$ of commercial fertilizers; and (2) $2 \mathrm{Mg}$ of Tithonia ha $^{-1}+75 \%$ of commercial fertilizers. In this case the reducing of commercial fertilizers application were $50 \%$ and $25 \%$, respectively.
\end{abstract}

Keywords: Iron toxicity, new paddy field, Tithonia, organic fertilizer,

\section{INTRODUCTION}

The diminution of rice field because of conversion to non-paddy fields in Indonesia, especially in Java, is the main cause of decline in rice production. Data reported by Agus (2011) showed that between 1981 and 2006, the average annual conversion was about 90,000 ha and the rate of conversion far exceeding that of development that caused the reduction in total lowland rice area from 8.4 million ha in 1993 to 7.8 million ha in 2006. It caused diminishing rice production and increased importation of rice to meet the national consumption every year. Peak of rice importation was occurred in year of 1998 as much as 5.9 million $\mathrm{Mg}$ (Sumodiningrat 2001), decline to 2.5 million $\mathrm{Mg}$ in

J Trop Soils, Vol. 17, No. 2, 2012: 135-142 ISSN 0852-257X year of 2002 and imported rice was still about 1 million $\mathrm{Mg}$ in year of 2009 (BPS 2010).

Development of new lowland paddy (NPF) area is one solution to overcome this problem. However, cultivation of rice at NPF face various problems, especially ferrous $\left(\mathrm{Fe}^{+2}\right)$ toxicity beside of the poor nutrient content in the soil. Flooding the NPF led to increase the reduction of insoluble $\mathrm{Fe}^{3+}$ to soluble $\mathrm{Fe}^{2+}$ form that potentially reaches peak values 2-8 weeks after soil flooding (Swarup 1988; Patra and Mohany 1994) and remains constant thereafter (Sadana et al. 1995). Ponnamperuma (1984); Becker and Asch (2005) found that the concentrations $\mathrm{Fe}^{2+}$ could become higher than $600 \mathrm{ppm}$ after two weeks of flooding and Sahrawat (2010) and Chérif et al. (2009) found in particular soil, $\mathrm{Fe}^{2+}$ content could reach higher than 2,000 ppm depend on the duration of submergence.

From a series of researches using Tithonia as organic fertilizer to improve soil fertility showed that 
Tithonia was able to improve soil fertility by reducing acid content and $\mathrm{Al}$ saturation of soil, increased soil $\mathrm{pH}$, soil organic mater content, and soil nutrient of $\mathrm{N}, \mathrm{P}, \mathrm{K}, \mathrm{Ca}$, and $\mathrm{Mg}$ levels (Hakim and Agustian 2003; Hakim et al. 2006). In addition, Gusnidar (2007) noted that decomposition of Tithonia releases the nutrients of $\mathrm{N}, \mathrm{P}, \mathrm{K}$, and others and also produce organic acids such as acetic, propionic, salicylic, citric, succinic, and tartaric acid. These organic acids potentially dissolve the insoluble form of $\mathrm{P}$ and $\mathrm{K}$ in soil that make it more available to plant and form chelate potentially with $\mathrm{Fe}$ and $\mathrm{Al}$.

Tithonia (Tithonia diversifolia) or Mexican sunflower is a shrub plant containing high nutrients particularly $\mathrm{N}$ and $\mathrm{K}$ about $3.5 \%$ and $4.1 \%$, respectively and $0.38 \% \mathrm{P}$, (Jama et al. 2000; Sanchez and Jama, 2000). Beside of high containing in $\mathrm{N}$ and $\mathrm{K}$, Tithonia also contains $\mathrm{Ca} 0.59 \%$, and Mg 0.27\% (Rutunga et al. 1999). Hakim (2002) reported that within the top of $50 \mathrm{~cm}$ of Tithonia collected from several locations in West Sumatra contained of nutrients with an average $3.16 \% \mathrm{~N}$; $0.38 \% \mathrm{P}$; and $3.45 \% \mathrm{~K}$.

Take and advantage from rapidity of Tithonia growth, it is shown that Tithonia can be cultivated in dry land of Ultisols as alley fence with $5 \mathrm{~m}$ width pattern $\left(2,000 \mathrm{~m}\right.$ row $\left.^{-1}\right)$ or as the garden fence with $10 \mathrm{~m} \times 10 \mathrm{~m}$ pattern $\left(1,900 \mathrm{~m}\right.$ row ha $\left.^{-1}\right)$, and it may be prunned every two months. With this Tithonia cultivation techniques, it produced 6.6 to $6.8 \mathrm{Mg}$ of dry matter (about $40 \mathrm{Mg}$ of fresh Tithonia) that contained about 150 to $240 \mathrm{~kg} \mathrm{~N}$ and 156 to $245 \mathrm{~kg} \mathrm{~K}$ nutrients per year per 0.20 ha (Hakim and Agustian (2003). Hakim et al. (2007) processed the biomass of Tithonia obtained into organic fertilizer Tithonia knows as "Organic Fertilizer Tithonia Plus" (OFTP) for corn and soybean on dry lands of Ultisol. The OFTP is organic fertilizer made from prunned Tithonia with Stardec and Trichoderma addition as decomposers, lime as $\mathrm{CaCO}_{3}$, paddy straw, and $\mathrm{N}, \mathrm{P}, \mathrm{K}$, and $\mathrm{Mg}$ nutrients in $\mathrm{CF}$ form equivalent to $50 \%$ crop needs. Utilization of OFTP to maize produced $6.7 \mathrm{Mg} \mathrm{ha}^{-1}$ of maize grain yield, and about $2.2 \mathrm{Mg} \mathrm{ha}^{-1}$ of soybean grain yield, whereas the application of $\mathrm{CF}$ was reduced as $50 \%$.

Based on the results obtained in dryland of Ultisol, OFTP can be expected to improve soil fertility of NPF, eliminate iron $\left(\mathrm{Fe}^{+2}\right)$ toxicity, as well as provide a number of nutrients $\mathrm{N}, \mathrm{P}, \mathrm{K}$, and $\mathrm{Mg}$ to support rice growth. Dharmasraya District is a newly area for the NPF development that are facing the problem of iron toxicity and low of soil fertility. Therefore, this research was conducted at the NPF in Sitiung, Dharmasraya district of West Sumatra province, Indonesia.

The research objectives were to find an appropriate formula of organic fertilizer Tithonia plus (OFTP) to alleviate of iron toxicity at the new paddy field (NPF), reduced the application of commercial fertilizers (CF) and simultaneously increased the production of rice.

\section{MATERIALS AND METHODS}

\section{Location and Experimental Designs}

Field experiment was conducted NPF area located in Sitiung, Koto Baru sub-district, Dharmasraya district, West Sumatra province of Indonesia. The experiments were done since August to November 2009. Soil were analysed in Soil Science Laboratory of Andalas University in Padang. The experiment was designed based on the results that obtained in pot experiments in greenhouse previously (Hakim et al. 2009). The factorial $2 \times 6$ in split plots design were used in this field experiment with 3 blocks as replication that gave 12 treatments combination. The main plot (A),

Table 1. The formulation of OFTP materials and the treatment combination assayed on the NPF in Sitiung, Dharmasraya district, West Sumatra province, Indonesia.

\begin{tabular}{|c|c|c|c|c|}
\hline \multirow{2}{*}{$\begin{array}{l}\text { Treatment } \\
\text { code }\end{array}$} & \multicolumn{2}{|l|}{ The formulation of OFTP (B) } & \multicolumn{2}{|c|}{ The ages of NPF(A) } \\
\hline & Tithonia, rice straw, and cow manure $\left(\mathrm{hh}^{-1}\right)$ & $\mathrm{CF}$ & 0 year (A1) & 2 years $(\mathrm{A} 2)$ \\
\hline B 1 & $2 \mathrm{Mg}$ Tithonia $+0 \mathrm{Mg}$ rice straw & $75 \%$ & A1 B1 & A2 B1 \\
\hline B 2 & $2 \mathrm{Mg}$ Tithonia $+5 \mathrm{Mg}$ rice straw & $50 \%$ & A1 B2 & A2 B2 \\
\hline B 3 & $4 \mathrm{Mg}$ Tithonia & $25 \%$ & A1 B3 & A2 B3 \\
\hline B 4 & 0 Tithonia $+5 \mathrm{Mg}$ rice straw & $75 \%$ & A1 B4 & A2 B4 \\
\hline B 5 & 0 Tithonia $+2 \mathrm{Mg}$ cow manure & $75 \%$ & A1 B5 & A2 B5 \\
\hline B 6 & $100 \% \mathrm{CF}$ & $100 \%$ & A1 B6 & A2 B6 \\
\hline
\end{tabular}

Note: The weight of Tithonia, paddy straw, and cow manure used are in constant dry weight. All of treatements were limed as $500 \mathrm{~kg} \mathrm{CaCO} 3 \mathrm{ha}^{-1} . \mathrm{OFTP}=$ organic fertilizer Tithonia plus, $\mathrm{NPF}=$ new paddy field, and $\mathrm{CF}$ $=$ commercial fertilizers. 
the age of the opening of NPF, were: 0 year; 2 years; Subplot (B), a formulation of OFTP, were: $2 \mathrm{Mg}$ Tithonia ha ${ }^{-1}+75 \%$ of CF; $2 \mathrm{Mg}$ Tithonia ha ${ }^{-1}+5$ $\mathrm{Mg} \mathrm{ha}{ }^{-1}$ rice straw $+50 \%$ of $\mathrm{CF} ; 4 \mathrm{Mg}$ Tithonia $\mathrm{ha}^{-1}+25 \%$ of $\mathrm{CF}$ and three treatments without Tithonia i.e. $5 \mathrm{Mg} \mathrm{ha}^{-1}$ rice straw $+75 \%$ of $\mathrm{CF}$; 2 $\mathrm{Mg} \mathrm{ha}^{-1}$ animal manure $+75 \% \mathrm{CF}$, and $100 \% \mathrm{CF}$. Liming with $500 \mathrm{~kg} \mathrm{CaCO}_{3}$ ha $^{-1}$ were applied for all treatments. The main plot was $24 \mathrm{~m} \times 6 \mathrm{~m}$, while the sub-plot was $4 \mathrm{~m} \times 6 \mathrm{~m}$.

\section{OFTP Processing}

Referring to the rice crop nutrient needs issued by Surowinoto (1982), the reference of fertilizers used per hectare were $100 \mathrm{~kg} \mathrm{~N}$ (225 kg Urea), 20 $\mathrm{kg}$ P (100 kg TSP), $125 \mathrm{~kg} \mathrm{~K}(250 \mathrm{~kg} \mathrm{KCl})$ and 16 $\mathrm{kg} \mathrm{Mg}$ (100 kg Kiserite). Based on the results of previous studies the average nutrient levels of Tithonia was $2.5 \% \mathrm{~N} ; 0.25 \% \mathrm{P}, 2.5 \% \mathrm{~K}$ and $0.25 \%$ $\mathrm{Mg}$. Therefore, to reach $100 \mathrm{~kg} \mathrm{~N}$, it needed Tithonia as much as $4 \mathrm{Mg}$ of dry weight and we treated Tithonia in two levels i.e. 2 and $4 \mathrm{Mg} \mathrm{ha}^{-1}$. Dry weight of rice straw used are fixed at $5 \mathrm{Mg} \mathrm{ha}^{-1}$.

The mix amount of Tithonia and rice straw were made to provide $\mathrm{N}$ nutrients for rice crops equivalent to $25,50,75$, and $100 \mathrm{~kg} \mathrm{~N}$, while the $\mathrm{P}$ and $\mathrm{K}$ were adjusted as default. According to Hakim et al. (2007), TSP, KCl, and Kiserit fertilizers were added at the beginning OFTP processing, while the $\mathrm{N}$ fertilizer was applied a half at planting and the rest at the age of 6 weeks after planting. The prunned Tithonia used was the top of $70-100 \mathrm{~cm}$ and the size of $3-5 \mathrm{~cm}$ rice straw was obtained by chopping in chopper machine. Inoculants of Trichoderma and stardec were added as biodecomposer to speed up the process of organic materials decomposition. Composted material was reversed after one week incubations and was periodically reversed in 3 days interval. The process was ended after 4 weeks of composting.

\section{Land Preparation and OFTP Application}

The main plot consists of two differences in age of NPF ( 0 and 2 years usage). Plow tillage was performed by hand tractors. Main plot and subplot were designed in such a way by digging a trench between the plot to avoid the water submergence as required by the SRI method. Organic fertilizer Tithonia plus was broadcasted on the soil surface, evenly plowing and incubated for three weeks in accordance to best incubation period of the previous obtained in pot experiment. After three weeks OFTP incubation period with soil, paddy soil was submerged and left for one week.
Planting, $\mathbf{N}$ fertilizing, Maintenance, and Harvesting

Two seedlings of $\mathrm{IR}_{66}$ variety with two weeks age were planted into each subplot in plant spacing $25 \mathrm{~cm} \times 25 \mathrm{~cm}$. Just before planting, one third of $\mathrm{N}$-fertilizer was applied in accordance with the treatment. Two third of $\mathrm{N}$-fertilizer was applied after 6 weeks planting. Crops were protected from pests and diseases. Soil moist condition was kept in field capacity and at the beginning of heading and milking stage, the plots were submerged as high as 2 $\mathrm{cm}$. Submergence was kept until the full grains filling. Crops harvest was done when the color of grain and the trunk were completely yellow.

\section{Soil Nutrients Analysis}

Soil samples were collected from the depth of $0-20 \mathrm{~cm}$ in each plot harvested area using a standard auger at the early planting and at the harvesting time. The samples were put into polythene bags and taken to the laboratory for analysis. The samples were air dried and sieved to pass $1 \mathrm{~mm}$ sieve. Soil chemical properties measured for soil early planting samples were $\mathrm{pH}$, Eh, organic $\mathrm{C}$, total $\mathrm{N}, \mathrm{NH}_{4}^{+}$and $\mathrm{NO}_{3}^{-}$ content, and $\mathrm{Fe}^{2+}$ content, Cation exchangeable capacity (CEC), exchangeable bases and available P. Exchangeable bases $\mathrm{Ca}, \mathrm{Mg}, \mathrm{K}, \mathrm{Na}$ were extracted by $1 M$ ammonium acetate ( $\mathrm{pH} 7) ; \mathrm{Ca}$ and $\mathrm{Mg}$ were determined on Perkin Elmer atomic absorption spectrophotometer and $\mathrm{K}$ on a flame photometer. Available P was analyzed by Bray II; total $\mathrm{N}$ by reguler Macro Kjeldahl Method, and organic $\mathrm{C}$ by Walkley and Black method. $\mathrm{Al}$ and $\mathrm{H}$ cations were extracted in $1 M \mathrm{KCl}$ solution according to Kamprath (1970). Effective cation exchange capacity (ECEC) was found by adding the exchangeable bases and the exchangeable acidity $\left(\mathrm{H}^{+}\right.$and $\left.\mathrm{Al}_{3}^{+}\right)$.

\section{Plant Observation}

Observations of the dry weight of plants included grain and straw. The differences due to treatment were analysed by analysis of variance $(F$ test) in accordance to factorial $2 \times 6$ with 3 blocks in split plot experimental design, and comparison of means were performed using honest significantly different (HSD).

\section{RESULTS AND DISCUSSION}

\section{Soil Chemical Properties}

Results of soil chemical properties that were influenced by the OFTP included $\mathrm{pH}, \mathrm{Eh}, \mathrm{Fe}^{2+}$, are 
Table 2. Soil $\mathrm{pH}, \mathrm{Eh}$, and $\mathrm{Fe}^{2+}$ on different ages of NPF, measured after 3 weeks incubated with OFTP

\begin{tabular}{|c|c|c|c|c|c|c|}
\hline \multirow{2}{*}{$\begin{array}{c}\text { Treatment } \\
\text { code }\end{array}$} & \multicolumn{2}{|c|}{$\mathrm{pH}$} & \multicolumn{2}{|c|}{ Eh $(\mathrm{mV})$} & \multicolumn{2}{|c|}{$\mathrm{Fe}^{2+}(\mathrm{ppm})$} \\
\hline & A1 & A2 & A1 & A2 & A1 & A2 \\
\hline B1 & 6.17 & 6.68 & 39.00 & 29.90 & 340 & 192 \\
\hline B2 & 6.10 & 6.26 & 58.20 & 51.40 & 395 & 154 \\
\hline B3 & 6.26 & 6.75 & 41.90 & 25.10 & 354 & 42 \\
\hline B4 & 6.65 & 6.48 & 32.20 & 32.50 & 404 & 120 \\
\hline B5 & 6.53 & 6.34 & 34.90 & 35.50 & 395 & 95 \\
\hline B6 & 6.05 & 5.81 & 60.50 & 73.80 & 398 & 121 \\
\hline Average & 6.29 & 6.39 & 42.78 & 41.37 & 381 & 91 \\
\hline
\end{tabular}

Table 3. The results of soil N, P and K analyses of the different NPF ages, measured after 3 weeks incubated with OFTP.

\begin{tabular}{ccccccccccr}
\hline \multirow{2}{*}{$\begin{array}{c}\text { Treatment } \\
\text { code }\end{array}$} & \multicolumn{2}{c}{$\mathrm{N}$-total $(\%)$} & \multicolumn{2}{c}{$\mathrm{NH}_{4}(\mathrm{ppm})$} & \multicolumn{2}{c}{$\mathrm{NO}_{3}(\mathrm{ppm})$} & \multicolumn{2}{c}{$\mathrm{P}(\mathrm{ppm})$} & \multicolumn{2}{c}{$\mathrm{K}\left({\left.\mathrm{me} 100 \mathrm{~g}^{-1}\right)}\right.$} \\
\cline { 2 - 11 } & $\mathrm{A} 1$ & $\mathrm{~A} 2$ & $\mathrm{~A} 1$ & $\mathrm{~A} 2$ & $\mathrm{~A} 1$ & $\mathrm{~A} 2$ & $\mathrm{~A} 1$ & $\mathrm{~A} 2$ & $\mathrm{~A} 1$ & $\mathrm{~A} 2$ \\
\hline $\mathrm{B} 1$ & 0.20 & 0.44 & 15.95 & 7.67 & 16.73 & 28.25 & 23.33 & 26.27 & 0.61 & 0.58 \\
$\mathrm{~B} 2$ & 0.19 & 0.22 & 38.93 & 17.69 & 15.65 & 34.57 & 18.04 & 27.27 & 0.52 & 0.80 \\
$\mathrm{~B} 3$ & 0.15 & 0.18 & 13.48 & 6.07 & 9.29 & 26.77 & 22.55 & 25.59 & 0.64 & 0.73 \\
$\mathrm{~B} 4$ & 0.12 & 0.16 & 25.84 & 6.53 & 11.52 & 12.27 & 23.90 & 28.18 & 0.67 & 0.60 \\
B5 & 0.16 & 0.41 & 30.85 & 9.00 & 16.36 & 14.87 & 28.29 & 21.87 & 0.72 & 0.78 \\
B6 & 0.17 & 0.14 & 10.21 & 6.53 & 10.41 & 23.42 & 27.05 & 22.09 & 0.66 & 0.76 \\
\hline Average & 0.17 & 0.26 & 22.54 & 8.92 & 13.32 & 23.35 & 23.86 & 25.22 & 0.64 & 0.70 \\
\hline
\end{tabular}

are presented in Tables 2, while the nitrogen in the form of total- $\mathrm{N}, \mathrm{NH}_{4}^{+}$, and $\mathrm{NO}_{3}^{-}$, available-P and exchg-K are in Table 3.

Data in Table 2 show that all treatments had a soil $\mathrm{pH}>6$. When compared to $\mathrm{B} 6$ (without giving OFTP or without using organic mater), it can be stated that using OFTP to 0 years NPF tended to increase the soil $\mathrm{pH}$ varied from 0.05 to 0.60 units, while in the 2 years NPF the $\mathrm{pH}$ increased 0.45 to 0.94 units. The increasing in soil $\mathrm{pH}$ at this treatment could be caused by adding $500 \mathrm{~kg}$ lime ha ${ }^{-1}$ in the OFTP formula. Other reason could be proposed that organic materials in the OFTP were capable to chelate $\mathrm{Al}$ and so it was not dissolve and could not donate ion $\mathrm{H}$. The average soil $\mathrm{pH}$ of 2 years NPF was 6.39, while in the 0 year NPF was 6.29 (Table 2). Soil $\mathrm{pH}$ in 2 years NPF about 0.10 units higher than 0 year NPF. It can be caused by the flooding that has lasted for 2 years or for 4 seasons planting time ago. Flooding causes transformed $\mathrm{Fe}^{+3}$ into $\mathrm{Fe}^{+2}$ and thus raises the $\mathrm{pH}$ because of $\mathrm{OH}$ release. Some of the soluble Fe was also leached with irrigation water. As raised by Ponnamperuma (1984) that if the paddy field flooded, it will lead to soil $\mathrm{pH} 7$ due to the reduction of $\mathrm{Fe}^{+3}$ to $\mathrm{Fe}^{+2}$ which produces $\mathrm{OH}$. Although in this experiment during the incubation period with OFTP soil was not flooded, but the change in 2 years NPF had occurred since the last four seasons, not only due to the addition OFTP.

Table 2 shows that the Eh values ranged between $32-61 \mathrm{mV}$ in 0 year NPFs, and $25-74 \mathrm{mV}$ on 2 years NPF. The highest Eh values was found in B6 (without OFTP). Thus it can be stated that OFTP is likely to lower the Eh. This is in line with the opinion of Patrick and Reddy (1978) who suggested that the addition of organic mater can lower the Eh. It can be caused by the moisture content during incubation OFTP when heavy rain, the water a little stagnant, resulting in reductive reactions. These reactions cause the Eh decreases with the provision of organic ingredients.

Table 2 also shows that the levels of $\mathrm{Fe}^{2+}$ average on Ultisol just cultivated ( 0 year NPF) contains about $381 \mathrm{ppm} \mathrm{Fe}^{2+}$, while in 2 years NPF was approximately $91 \mathrm{ppm}$. It shows that at the age of 2 years NPF, that has been given the stagnant water and flowed continuously for 4 seasons ago. There has been $\mathrm{Fe}^{2+}$ leaching so that do lower levels of $\mathrm{Fe}^{2+}$ In contrast to the NPF that had just cultivated and not flooded $\mathrm{Fe}^{2+}$ leaching has not happened yet. When observed the effect of giving OFTP to the solubility of $\mathrm{Fe}^{2+}$, visible effects are not consistent (Table 2). 
In this case, the results of the analysis compared to B6, which was land without OFTP, but it got $500 \mathrm{~kg} \mathrm{CaCO} 3 \mathrm{ha}^{-1}$. At the age of 0 year NPF, application of OFTP was likely to lower the solubility of $\mathrm{Fe}^{2+}$, except at B4 (5 Mg of rice straw $\left.\mathrm{ha}^{-1}\right)$. Here can be calculated, that the rather large declining of $\mathrm{Fe}^{2+}$ occured in B1 (2 Mg Tithonia ha-1) and B2 $\left(2 \mathrm{Mg}\right.$ Tithonia ha ${ }^{-1}+5 \mathrm{Mg}$ rice straw ha' $\left.{ }^{-1}\right)$, respectively by $58 \mathrm{ppm}$ and $44 \mathrm{ppm}$. On 2 years NPF, compared it with B6 treatment, decreasing the solubility of $\mathrm{Fe}^{2+}$ occured only in $\mathrm{B} 3$ treatment (4 Mg Tithonia ha ${ }^{-1}$ ) and B5 (2 Mg cow manure ha $\left.{ }^{1}\right)$, respectively at 79 and $26 \mathrm{ppm} \mathrm{Fe}^{2+}$, whereas the B1 treatment (2 Mg Tithonia ha ${ }^{-1}$ ) and B2 (2 $\mathrm{Mg} \mathrm{ha}^{-1}+5$ Tithonia Mg straw ha-1) increased slightly.

Decreasing the solubility of $\mathrm{Fe}^{2+}$ due to the addition OFTP as a source of organic mater can be caused by the reaction of $\mathrm{Fe}^{2+}$ chelation by organic acids, mainly from Tithonia. Gusnidar (2007) reported that the Tithonia, in addition to producing the nutrients $\mathrm{N}, \mathrm{P}, \mathrm{K}$, also produces organic acids such as acetic, propionate, salicylic, citric, succinic, and tartaric acid. Organic acids can chelate $\mathrm{Fe}^{2+}$, so that its solubility is reduced. The existence of a slight increase of $\mathrm{Fe}^{2+}$ solubility with the addition of $\mathrm{B} 1$ and B2 OFTP allegedly due to the occurrence of redox reactions at a certain time, for example when it rains that causing stagnant water in the plot.

Furthermore, Table 3 shows that the average content of $\mathrm{N}$-total in 2 years NPF $(0.26 \%)$ was much higher than the age of 0 year $(0.17 \%)$. Higher levels of total-N may be caused by the residual of fertilizers and paddy straw from the four seasons ago at 2 years NPF. In 0 year NPFs, an increasing of total-N were only on treatment OFTP B1 and B2, whereas in 2 years NPF increasing total-N was occurred in all treatments with a slightly different scale.

When observed changes in soil $\mathrm{N}$ after incubated with OFTP for 3 weeks (Table 3), then it can be stated that the average of $\mathrm{NH}_{4}$ on 0 year NPF (23 ppm) was much higher than 2 years NPF $(9 \mathrm{ppm})$. In contrast, the average content of $\mathrm{NO}_{3}$ on 0 years NPF (13 ppm) was much lower than $2^{3}$ years NPF (23 ppm). Thus, it can mean that were changeing in $\mathrm{N}$ compounds that in 0 year $\mathrm{NPF} \mathrm{NH}_{4}^{+}$ was dominant, while in 2 years NPF it has continued into $\mathrm{NO}_{3}$ form. It can be caused by differences in microorganisms decomposer $\mathrm{N}$. Allegedly to 0 year $\mathrm{NPF}$, the number of microbial $\mathrm{N}$ decomposer was still limited because of dry land has just turned into rice fields. In contrast to 2 years NPF that has been planted with four seasons ago, and allows the amount of microbial $\mathrm{N}$ decomposes were more severe due to a number of nutrients were available and the amount of organic material as energy sources were also available. In addition, the remaining organic matter from four seasons ago had previously experienced renovation, so that more $\mathrm{NO}_{3}$ available.

If the amount of $\mathrm{NH}_{4}$ and $\mathrm{NO}_{3}$ in Table 3 are summed, then 0 year NPF there as much as 35.86 ppm, while in 2 years NPF was $32.27 \mathrm{ppm}$. The amount was relatively similar. In terms of average number of N-total in 0 year NPF $(0.17 \%)$ was lower than 2 years NPF $(0.26 \%)$. In this case it can be stated that some $\mathrm{N}$ was immobilized because decomposition $\mathrm{N}$ was not finished.

In Table 3 can be seen that the lowest of available-P at 0 year NPF was found at B2 (18 ppm)

Tabel 4. Rice grain yield and paddy straw of IR $_{66}$ variety as effected by OFTP and age of NPF in Sitiung, Koto Baru sub-distric, Dharmasraya distric of West Sumatra Province, Indonesia.

\begin{tabular}{|c|c|c|c|c|c|c|}
\hline \multirow{3}{*}{$\begin{array}{c}\text { Formula } \\
\text { OFTP }\end{array}$} & \multirow{2}{*}{\multicolumn{2}{|c|}{$\begin{array}{c}\text { Dry weigh of grain yield } \\
\left(\mathrm{Mg} \mathrm{ha}^{-1}\right)\end{array}$}} & \multirow{3}{*}{$\begin{array}{c}\text { Main effect } \\
\text { OFTP } \\
0 \text { year }\end{array}$} & \multirow{2}{*}{\multicolumn{2}{|c|}{$\begin{array}{c}\begin{array}{c}\text { Dry weigh of rice straw } \\
\left(\mathrm{Mg} \mathrm{ha}^{-1}\right)\end{array} \\
\text { Paddy field age }\end{array}$}} & \multirow{3}{*}{$\begin{array}{c}\text { Main effect } \\
\text { OFTP } \\
2 \text { years }\end{array}$} \\
\hline & & & & & & \\
\hline & 0 year & 2 years & & 2 years & 0 year & \\
\hline B1 & $4.08 \mathrm{a}$ & $4.17 \mathrm{a}$ & $4.13 \mathrm{a}$ & $7.45 \mathrm{a}$ & $5.21 \mathrm{a}$ & $6.33 \mathrm{a}$ \\
\hline B2 & $4.02 \mathrm{a}$ & $3.74 \mathrm{ab}$ & $3.88 \mathrm{a}$ & $6.99 \mathrm{a}$ & $4.39 \mathrm{a}$ & $5.69 \mathrm{a}$ \\
\hline B3 & $2.36 \mathrm{~b}$ & $3.14 \mathrm{~b}$ & $2.75 \mathrm{~b}$ & $6.59 \mathrm{a}$ & $3.92 \mathrm{a}$ & $5.26 \mathrm{a}$ \\
\hline B4 & $3.57 \mathrm{ab}$ & $4.25 \mathrm{a}$ & $3.91 \mathrm{a}$ & $6.97 \mathrm{a}$ & $5.24 \mathrm{a}$ & $6.11 \mathrm{a}$ \\
\hline B5 & $2.08 \mathrm{~b}$ & $4.96 \mathrm{a}$ & $3.52 \mathrm{ab}$ & $7.07 \mathrm{a}$ & $5.91 \mathrm{a}$ & $6.49 \mathrm{a}$ \\
\hline B6 & $3.06 \mathrm{ab}$ & $4.65 \mathrm{a}$ & $3.86 \mathrm{a}$ & $7.90 \mathrm{a}$ & $5.57 \mathrm{a}$ & $6.74 \mathrm{a}$ \\
\hline $\begin{array}{l}\text { Main effect Paddy } \\
\text { field age }\end{array}$ & $3.20 \mathrm{~A}$ & $4.15 \mathrm{~A}$ & & $7.16 \mathrm{~A}$ & $5.04 \mathrm{~B}$ & \\
\hline
\end{tabular}

Numbers followed by the same letters in the same column showed non significant different at 5\% HSD test Number followed by different capital letters in the same row showed significantly different at $5 \%$ level HSD. 
and the highest was in B5 (28 ppm), while in 2 years NPF instead of the lowest was in B5 (22 ppm) and the highest was at B4 (28 ppm). Average levels of available-P on 0 year NPFs (23.86 ppm) was slightly lower than 2 years NPF field (25.22 ppm). Higher levels of $\mathrm{P}$ and $\mathrm{K}$ in 2 years NPF could be caused by residual fertilizer $\mathrm{P}$ and $\mathrm{K}$ that were given four seasons ago.

\section{Rice Grain yield and Straw}

Grain yield of rice as the ultimate goal of providing OFTP treatment is presented in Table 4. Results of statistically analysis show that there was significant interaction effect between age of NPF and OFTP to the grain yield of rice. In Table 4 , it appears that rice grain yield at 2 years NPF was higher by $0.95 \mathrm{Mg} \mathrm{ha}^{-1}$ when compared with 0 year NPF, but it was not significantly different. Conversely, the results of dry straw significantly were higher as much as $2.12 \mathrm{Mg} \mathrm{ha}^{-1}$ at 0 year NPF than 2 years NPF. If the grain yield and straw dry summed (total biomass), then on 0 year NPF gained $10.36 \mathrm{Mg} \mathrm{ha}^{-1}$ and as much as 10.25 $\mathrm{Mg} \mathrm{ha}^{-1}$ in 2 years NPF. That was, the amount of the produced biomass was relatively the same, but higher grain yield was found at 2 years NPF, while paddy straw was higher in 0 year NPF. Comparison of grain weight of paddy straw, at 0 year NPFs was $45 \%$, while in 2 years NPF was about $82 \%$. Based on differences in grain yield and straw in both age those NPF, it can be stated that 0 year NPFs was less efficient in producing grain, while 2 years NPF field was more efficiently.

From observations in the field, vegetative growth was more prominent than generative in 0 year NPFs. It can be caused by nutrient availability are less balanced between $\mathrm{N}$ and P. In Table 3 it appears that the availability of $\mathrm{N}$ in the form of $\mathrm{NH}_{4}$ was much higher in 0 year NPF (average 22.54 ppm), while in 2 years NPF was much lower (average $8.92 \mathrm{ppm}$ ). However, the availability of $\mathrm{N}$ in the form of $\mathrm{NO}_{3}$ was lower in 0 year NPFs (average $13.32 \mathrm{ppm}$ ), while in 2 years NPF was higher (average $23.35 \mathrm{ppm}$ ). On the other hand, the rate-available $\mathrm{P}$ at 0 years NPF was slightly lower (average $23.86 \mathrm{ppm}$ ) than 2 years NPF (average $25.22 \mathrm{ppm})$.

It seems that the availability of $\mathrm{NH}_{4}$ and $\mathrm{P}$ were not comparable to 0 years NPF, resulting in lower grain, while the straw was much higher. Conversely, at 2 years NPF the available-P content was slightly higher (average $25.22 \mathrm{ppm}$ ), it seemed more balanced with $\mathrm{NO}_{3}$, resulting in higher grain, while straw was lower. In addition, lower grain yield in 0 year NPF compared with 2 years NPF, it was also due to the solubility of iron was higher than 2 years NPF (Table 2). Ren (1985), reported that the critical threshold levels of $\mathrm{Fe}^{2+}$ which poisoned the soil solution was 50-100 ppm. Breemen and Moormann (1978) stated that the $\mathrm{Fe}^{2+}$ toxicity in rice plants can occur when soil levels of $\mathrm{Fe}^{2+}$ reached 300 ppm. Accordingly, it can be stated that the growth of rice would not be optimal at the newly opened (age 0 years) because it contains $\mathrm{Fe}^{2+}$ of about 340$404 \mathrm{ppm}$ (Tabel 2) although it has given the OFTP. Conversely, at 2 years NPF $\mathrm{Fe}^{2+}$ levels between 42-121 ppm, thus providing a higher grain yield. Samaranayake et al. (2012) reported that by adding $250 \mathrm{mg} \mathrm{Fe}^{2+} \mathrm{L}^{-1}$ as $\mathrm{FeSO}_{4}$ to the rice culture solution.

Based on grain yield in Table 4 and in accordance with the purpose of research, namely to determine the appropriate formula of OFTP at 0 year NPF and 2 years NPFs the following will be explained the OFTP influence on grain yield in both NPF age.

At 0 year NPFs, grain yield that relatively equal and higher than other treatments were obtained in the treatment B1 (2 Mg Tithonia ha $\left.{ }^{-1}+75 \% \mathrm{CF}\right)$ and B2 $\left(2 \mathrm{Mg}\right.$ Tithonia ha ${ }^{-1}+5 \mathrm{Mg}^{2}$ paddy straw $\mathrm{ha}^{-1}+50 \%$ of $\mathrm{CF}$ ), namely 4.08 and $4.02 \mathrm{Mg} \mathrm{ha}^{-1}$ (Table 4). Grain yields in both formulas of OFTP were not significantly different between the treatment B4 (5 Mg straw ha $\left.{ }^{-1}+75 \% \mathrm{CF}\right)$ and B6 $(100 \% \mathrm{CF})$, but it was significantly different between the treatment B3 (4 Mg Tithonia ha ${ }^{-1}+25 \% \mathrm{CF}$ ) and B5 (2 $\mathrm{Mg}$ cow manure $\mathrm{ha}^{-1}+75 \%$ $\mathrm{CF})$. Compared to the treatment of $100 \% \mathrm{CF}$, both $\mathrm{B} 1$ and $\mathrm{B} 2$ formula OFTP increased grain yield by 1.02 and $0.96 \mathrm{Mg} \mathrm{ha}^{-1}$ or equal to 33 and $30 \%$. Remembering always produced the paddy straw each time of harvest, and CF can be reduced by $50 \%$, then it can be stated that the formula that made OFTP Tithonia from $2 \mathrm{Mg}$ Tithonia ha ${ }^{-1}+5$ $\mathrm{Mg}$ paddy straw ha ${ }^{-1}+50 \%$ of CF (B2) was a more appropriate choice in order to obtain grain yield about $4 \mathrm{Mg} \mathrm{ha}^{-1}$ in the NPF of Ultisol.

At 2 years NPF, Table 4 shows that the highest grain yield was obtained in the $\mathrm{B} 5$ treatment $(2 \mathrm{Mg}$ cow manure $\mathrm{ha}^{-1}+75 \%$ of $\mathrm{CF}$ ) with results of 4.96 $\mathrm{Mg} \mathrm{ha}{ }^{-1}$. These results were not significantly different from the treatment $100 \% \mathrm{CF}$, but it was higher as much as $0.31 \mathrm{Mg} \mathrm{ha}^{-1}$ or about $7 \%$. The results were also not significantly different between B1 and B2 which was the OFTP. Thus, it can be stated that in 2 years NPF, there were a lot of options to overcome iron toxicity, so obtained rice grain yields were higher (about $4 \mathrm{Mg} \mathrm{ha}^{-1}$ ) in the form of compost $5 \mathrm{Mg}$ paddy straw ha ${ }^{-1}+75 \% \mathrm{CF}$, or OFTP from 2 
Mg Tithonia $\mathrm{ha}^{-1}+75 \% \mathrm{CF}$, or OFTP from $2 \mathrm{Mg}$ Tithonia ha ${ }^{-1}+5 \mathrm{Mg}$ straw ha-1 $+50 \% \mathrm{CF}$ or compost from $2 \mathrm{Mg}$ of cow manure ha-1 $+75 \%$ of $\mathrm{CF}$. All treatments were added $\mathrm{CaCO} 3$ equivalent to $500 \mathrm{~kg} \mathrm{ha}^{-1}$.

In Table 4 also shows that the treatment B3 (OFTP Tithonia of $4 \mathrm{Mg}$ ha- $1+25 \% \mathrm{CF}$ ) gives a low grain yield in both fields age of 0 year $(2.36 \mathrm{Mg}$ ha-1) and 2 years (3.14 Mg ha-1), and it was significantly different to the other treatments. It can be caused by $\mathrm{CF}$ was given at low dosage (only $25 \%$ of rice needs), while the decaying Tithonia was not perfect, so the plants suffered from nutrient deficiencies. In other words, the reduction of CF by up to $75 \%$ with OFTP has not been able to give high yields. Therefore, the right choice was application of OFTP to reduce CF by $50 \%$. It was OFTP from $2 \mathrm{Mg}$ Tithonia ha ${ }^{-1}+5 \mathrm{Mg}$ paddy straw $\mathrm{ha}^{-1}+50 \% \mathrm{CF}$.

To conclude these results, it also noted the average rice grain yield of NPF 0 and 2 years, about $4 \mathrm{Mg} \mathrm{ha}^{-1}$ grain (moisture content 14\%) was obtained with the use of OFTP NPF in Sitiung can be expressed a very satisfactory results because the results obtained by farmers in NPF were only about 2 - $2.5 \mathrm{Mg} \mathrm{ha}^{-1}$ (observed directly in farmers' sawah around it). Grain yield of about $4 \mathrm{Mg} \mathrm{ha}^{-1}$ was already equal to the average rice yields in West. Sumatra which ranged from 4 to $5.5 \mathrm{Mg} \mathrm{ha}^{-1}$ However, grain yield $4 \mathrm{Mg} \mathrm{ha}^{-1}$ was still far below the rice yield in intensification sawah that have been steady. Gusnidar (2007) reported that the rice intensification program which has been implementing since the 1970s in Sicincin, Pariaman District of West Sumatra province, obtained a high grain yield. With the use of $2.5 \mathrm{Mg}$ Tithonia $+150 \mathrm{~kg}$ Urea and $19 \mathrm{~kg}$ $\mathrm{ha}^{-1} \mathrm{SP} 36$, the grain yield obtained was $8 \mathrm{Mg} \mathrm{ha}^{-1}$. The potential grain yield as much as $8 \mathrm{Mg} \mathrm{ha}^{-1}$ a target to reach by using OFTP continuously in NPF.

\section{CONCLUSIONS}

Utilization of organic fertilizer Tithonia plus (OFTP) could reduce $\mathrm{Fe}^{+2}$ solubility and enhanced levels of nutrients availability such as N, P, and K on new paddy field (NPF). The formulation of OFTP that more appropriate to control the iron toxicity and reduced the application of commercial fertilizers (CF) to get higher than $4 \mathrm{Mg} \mathrm{ha}^{-1}$ rice grain yield at new paddy field (NPF) were two options: (1) $2 \mathrm{Mg}$ of Tithonia ha ${ }^{-1}+5 \mathrm{Mg}$ of paddy straw ha ${ }^{-1}+50 \%$ of commercial fertilizers; and (2) $2 \mathrm{Mg}$ of Tithonia $\mathrm{ha}^{-1}+75 \%$ of commercial fertilizers. In this case the reducing of commercial fertilizers application were $50 \%$ and $25 \%$, respectively.

\section{ACKNOWLEDGEMENTS}

The authors would like to thank to Director of KKP3T Program, Department of Agriculture Republic of Indonesia for financial support. We also thank to Deno, Welly, and Ella for their laboratory assistance.

\section{REFERENCES}

Agus F. 2011. Environmental and sustainability issues of Indonesian agriculture. J Litbang Pert 30 (4): 140-147.

Asch F, M Becker and DS. Kpongor. 2005. A quick and efficient screen for resistance to iron toxicity in lowland rice. J Plant Nutr Soil Sci 168: 764-773.

Becker $\mathrm{M}$ and F Asch. 2005. Iron toxicity in riceconditions and management concepts. J Plant Nutr Soil Sci 168: 558-573.

BPS [Badan Pusat Statistik]. 2010. Statistik Indonesia. Badan Pusat Statistik. Jakarta: 149-363 (in Indonesian).

Breemeen NV and FR Moormann. 1978. Iron toxic soil. In: Soil and Rice IRRI. Los BaNPF. Philippines, pp. 781-800.

Chérif M, A Audebert, M Fofana and M Zouzou. 2009. Evaluation of iron toxicity on lowland irrigated rice in West Africa. Tropicultura 27 (2): 88-92.

Gusnidar. 2007. Budidaya dan pemanfaatan Tithonia diversifolia untuk menghemat pemupukan $\mathrm{N}, \mathrm{P}$, dan $\mathrm{K}$ padi sawah intensifikasi. Disertasi Doktor Ilmu Pertanian Program Pascasarjana Unand. Padang, (in Indonesian).

Hakim N dan Agustian. 2003. Gulma Tithonia dan pemanfaatannya sebagai sumber bahan organik dan unsur hara untuk tanaman hortikultura. Laporan Penelitian Tahun I Hibah Bersaing XI/I. Proyek Peningkatan Penelitian Perguruan Tinggi DP3M Ditjen Dikti. Lembaga Penelitian Unand. Padang, (in Indonesian).

Hakim N, L Arfania, I Darfis, Agustian and Hermansah. 2007. Pemanfaatan agen hayati dalam budidaya dan pemanfaatan Tithonia sebagai pupuk alternative dan pengendali erosi pada Ultisol. Laporan Penelitian Hibah Program Pascasarjana Tahun I. DP2M Ditjen Dikti dan Program Pascasarjanan. Unand Padang, (in Indonesian).

Hakim N, L. Arfania, and I Darfis. 2006. Efek sisa dan tambahan Tithonia terhadap sifat kimia Ultisol dan hasil tanaman jagung pada musim ke tiga. Laporan Penelitian SP4 Fak.Pertanian Unand. Padang, (in Indonesian).

Hakim N, Y Mala and Agustian. 2009. Pembuatan dan pemanfaatan pupuk organik Tithonia plus dalam penerapan metode SRI pada sawah bukaan baru. Laporan Hasil Penelitian KKP3T Tahun I. LPUnand dan Balitbang Pertanian Deptan. 61 p. (in Indonesian). 
Hakim N. 2002. Kemungkinan penggunaan Tithonia diversifolia sebagai sumber bahan organik dan unsur hara. J Andalas Bid Pert 38: 80-89.

Jama BA, CA Palm, RJ Buresh, AI Niang, C Gachengo, G Nziguheba and B Amadalo. 2000. Tithonia diversifolia as a green manure for soil fertility improvement in western Kenya: a review. Agrofores Syst 49: 201-221.

Kamprath EJ. 1970. Exchangeable aluminum as a criterion for liming leached mineral soils. Soil Sci Soc Amer Proc 34: 252-254.

Patra BN and SK Mohany. 1994. Effects of nutrients and liming on changes in $\mathrm{pH}$, redox potential and uptake of iron and manganese by wetland rice in iron-toxic soil. Biol Fertil Soils 17: 285-288.

Patrick WH and CN Reddy. 1978. Chemical changes in rice soil. In: Soil and Rice. The International Rice Institute. Los BaNPF. Laguna. Philipines, pp. 361-379.

Ponnamperuma FN. 1984. Chemical kinetics of Wetland Rice Soil and the Growth of Rice. In: Weet Land Soils. Charterization, Classificationand Utilization. IRRI. Los BaNPF. Philiphines, pp. 421-439

Ren YT. 1985. Physical chemistry of paddy soils. Science Press Beijing Springer-verlag.

Rutunga V, NK Karanja, CKK Gachene and CA Palm. 1999. Biomass production and nutrient accumulation by Tephrosia vogelli and Tithonia diversifolia fallows during six month growth at Maseno. Biotech Agron Soc Environ 3: 237-246.
Sadana US, DS Chahal and J Abadia. 1995. Iron availability, electrochemical changes and nutrient content of rice as influenced by green manuring in a submerged soil. Iron nutrition in soils and plants. Develop Plant Soil Sci 59: 105-109.

Sahrawat KL. 2010. Reducing iron toxicity in lowland rice with tolerant genotypes and plant nutrition. Plant Stress 4: 70-75.

Samaranayake P, BD Peiris and S Dssanayake. 2012. Effect of excessive Ferrous $\left(\mathrm{Fe}^{2+}\right)$ on growth and iron content in rice (Oryza sativa). Int J Agric Biol 14 (2): 296-298.

Sanchez PA and BA Jama. 2000. Soil fertility replenishment takes off in East and Southern Africa. Intenational Symposium on Balanced Nutrient Management Systems for the Moist Savanna and Humid Forest zones of Africa.Held on 9 Oct 2000 in Benin, Africa.

Sumodiningrat G. 2001. Menuju Swasembada Pangan. Revolusi Hajau II. Introduksi Manajemen dalam Pertanian. Penerbit RBI. Jakarta 181 halaman..

Surowinoto S. 1982. Teknologi Produksi Tanaman Padi Sawah. IPB. Bogor. 81 halaman

Swarup A. 1988. Effect of gypsum, farmyard manure and rice husk on the availability of iron and manganese to rice in submerged sodic soil. Oryza 38: $42-42$. 